UDC 347.235

DOI https://doi.org/10.32849/2663-5313/2021.10.04

\title{
Nataliia Bondarchuk,
}

PhD in Law, Associate Professor, Polissia National University, 7, Stariy boulevard, Zhytomyr, Ukraine, postal code 10002, bondarchnat@ukr.net

ORCID: orcid.org/0000-0001-8432-6275

\section{Nataliia Likhtanska,}

Master Student (Law), Polissia National University, 7, Stariy boulevard, Zhytomyr, Ukraine, postal code 10002, lihtanskaa@gmail.com

ORCID: orcid.org/0000-0002-8963-9403

\section{Olena Tyshkevych,}

Master Student (Law), Polissia National University, 7, Stariy boulevard, Zhytomyr, Ukraine, postal code 10002, olenatiskevic@gmail.com

ORCID: orcid.org/0000-0003-4589-2914

Bondarchuk, Nataliia, Likhtanska, Nataliia, Tyshkevych, Olena (2021). Current issues of land taxation mechanism in Ukraine in the context of agricultural land market. Entrepreneurship, Economy and Law, 10, 23-29, doi https://doi.org/10.32849/2663-5313/2021.10.04

\section{CURRENT ISSUES OF LAND TAXATION MECHANISM IN UKRAINE IN THE CONTEXT OF AGRICULTURAL LAND MARKET}

Abstract. The purpose of the article is to analyze the current land, civil, tax legislation and doctrinal sources to clarify the essence and legal nature of land fees in the context of the agricultural land market, identify and analyze the main problems and shortcomings of pricing and collecting land fees, and the place and role of this tax in the structure of revenues of local budgets of Ukraine. To define the concept of "land fee" and "land market" in the taxation system of Ukraine, the authors analyze the framework of categories and concepts of the study, specify land fees in terms of the land market and chief shortcomings of pricing and the mechanism of collecting land fees. General theoretical proposals for the enhancement of the relevant institution are formulated.

Research methods. The work is based on general scientific and special methods of scientific knowledge.

Results. The authors draw attention to the fact that the legislation of Ukraine needs to be reformed in terms of the systematization of mandatory payments for land owners and users through enshrining in the Tax Code of Ukraine a single mandatory payment for the relevant taxpayers - land fees. In the case of implementation of this proposal at the legislative level, the land fee can be understood as a mandatory fee paid by landowners and users (physical and legal entities) to local budget for an efficient and rational use of land as the main national wealth of Ukraine. The article highlights the major shortcomings of the current mechanism for pricing and collecting land tax. It is noted that the improvement of the efficiency of land tax is associated with the implementation of the rental concept of taxation aimed at collecting land rent driven by the advantages of location, fertility, and quality of the land. The authors outline principal directions for the improvement of the system of pricing and collecting land fees.

Conclusions. It is determined that land tax is one of the most important ways to increase the economic efficiency of agricultural producers. The authors conclude that the establishment of land tax should take place as follows: first, in proportion to income, economically and environmentally sound; secondly, it should not burden a payer with a high rate, or a complicated payment procedure or its inconvenient terms; third, tax rates should be in regression dependence on the dynamics of the quality of agricultural land; fourth, it is necessary to include it in a single system of financial circulation that its deduction and further use result in, at least, an indirect return to taxpayers through its targeted focus on environmental needs.

Key words: land payment, land tax, taxation mechanism, state policy, investment policy. 


\section{Introduction}

An essential component of effective land relations is a balanced fiscal policy of public authorities in land use. The fundamental basis of the organization of land management in almost all civilized countries is the taxation system. The selection of the strategy for developing the land market and forms of its state regulation in Ukraine should rest upon the national particularities of land relations, taking into account the existing factors of socio-economic development. Given the unique importance of the natural factor in the formation of national income and the lifting of the moratorium on the sale of agricultural land, the current task is to make adequate changes in the tax system.

In the course of unfolding financial turmoil, and thus, the volatile macroeconomic environment and escalating problems with pumping up budgets, the consideration of the effectiveness of the land tax mechanism in Ukraine becomes particularly relevant. Unfortunately, the benefits of collecting land tax in domestic practice are not fully attained due to many problems, key one of which is the inconsistency of the mechanisms of collecting land fees with modern market processes

Moreover, with the development of Ukraine's market economy and state environmental policy, it is essential to revise the essence and social role of the land fee as a type of tax amidst the agricultural land market, which is deducted to use the land as the main national wealth of Ukraine effectively and rationally, through analyzing its financial and legal regulation, identifying shortcomings of the specified regulatory impact, and formulating proposals for their elimination.

Analysis of recent researches and publications. A set of statutory acts of Ukraine conducted legislative regulation of land relations and their taxation. Many scientific contributions are devoted to land use taxation and the market of agricultural lands. In particular, the legal aspects of land fees were studied by such scientists as Maksymchuk O.O., Pavlenko E.B., Horyn V.P., Bulavynets V.M., Bohatyrov Ye.M, et al. Some aspects of the agricultural land market were elucidated in the works by Korobska A.O., Stupen N.H., Ryzhok Z.R., Taratula R.B., Salnykova T.V., Kolesnik Ye.O., Silina I.S., et al. The mechanism of land taxation is covered by Babii K., Pavlii A.S., Myshchyshyn I.R., Sydorovych O.Iu., Rudnytska Yu.V., et al. However, despite a bulk of scientific papers, the issue of creating an appropriate mechanism for collecting land fees in the context of the agricultural land market as a result of constant changes in society is still poorly studied.

The purpose of the research is the analysis of current land, civil, tax legislation, and doc- trinal sources to clarify the essence and legal nature of land fees in terms of the agricultural land market, identification and analysis of major challenges and shortcomings in pricing and collecting land fees, as well as determination of the place and role of the relevant tax in the structure of revenues of local budgets of Ukraine. The main tasks are: to clarify the content of land fees in the context of the agricultural land market; to determine the place of land fees in the structure of revenues of local budgets of Ukraine; to identify the fundamental shortcomings of the mechanism of collecting land fees in the context of the agricultural land market; to suggest ways to address them.

2. Theoretical-legal approaches to the content and nature of land fees in the context of the agricultural land market

The principal root of the existing difficulties in the legal regulation of land fees in general and in the context of the agricultural land market, in particular, is the lack of a common interpretation of the concepts of "land fee" and "land market". Although the legislator actively uses the above terms, including in the fundamental act - the Land Code of Ukraine, neither the Code or any other statutory legal act contain their official interpretation. Most experts agree that the lack of a legal definition of "land fee" and "agricultural land market" is a significant gap in Ukrainian legislation, which creates difficulties in the practical application of land law.

Considering the term "land fee", it is worth noting that the very term is not yet a legal category. From a syntactic point of view, it is a substantive phrase with the main word "land" and its subordinate "fee" (Plotnikova, 2015, p. 44). It should be stated that the legal definition of a land fee indicates that it consists of two other taxes: rent for state or communal land plots and land tax, which in their legal definitions are separated from other taxes and fees by specifying a list of tax payers: 1) landholders; 2) owners of land shares; 3 ) permanent land users; 4) tenants of land plots of state and communal ownership.

V.I. Fedorovich's opinion, who interprets a land fee as a common name for all types of mandatory payments paid in terms of the exercise of a private right to property and other real rights in land, generates interest (Shulha, 2019, p. 446). However, it is essential to mark that this definition demonstrates exclusively private law nature of the land fee without considering its essential features, in particular the fact that under para. 3 of art. 78 of the Land Code of Ukraine (LCU), land in Ukraine may be not only in private but also communal and state ownership. Land fees are also paid for the use 
of communal and state-owned lands by payers, which are not only individuals and legal entities as subjects of private law but also territorial communities and the state, including as subjects of public law.

The authors of the textbook "Tax Law of Ukraine" edited by O. P. Hetmanets and O. M. Shumila define the land fee by dividing it into two components: land tax and rent for the land of state and communal ownership. At the same time, they argue that the social significance of land fees involves both increasing the relevant budgets or realizing the economic interests of the owner and stimulating efficient and rational land use (Hetmanets, Shumila, Pokotaieva, 2013, p. 232).

In reviewing and analyzing the scientific literature regarding the scope of the concept "land fee" in the context of the agricultural land market, it is necessary to clarify the essence of the agricultural land market. It should be noted that the concept of the land market does not have an unambiguous interpretation, as it is often identified with land turnover. For example, E. N. Krylatykh defines the land market as part of land turnover under which establishment, change of prices, and termination of land rights occurs as a result of a legally executed contract and is intermediated by cash or in-kind payment. The land market encompasses such types of transactions as the purchase and sale of land (land shares), land lease, pledge of the land plot to obtain credit (Krylatykh, 1997, p. 35). I. A. Ikonytska has a different view pointing out that the land market covers more deals on land plots, which are free of charge, including transactions for the transfer of land ownership based on an annuity and lifetime maintenance agreement (Ikonitskaya, 2005, p. 241).

V. I. Nazarenko and H. I. Shmelov interpret the land market even broader. Thus, according to the authors, the land market should be understood not as the very fact (or the right) of land transfer from one owner to another by purchase and sale, but as the whole complex of relations on the movement of lands from one user to another. This means that the land market includes all transactions for its sale, lease, exchange, inheritance, sublease, temporary use, as well as certain forms of transfer of relevant legal rights (Nazarenko, Shmelev, 2005, p. 112). Moreover, V.I. Nazarenko and H.I. Shmelev highlight that the land market should rely on well-defined legislation, bylaws, the availability of corresponding market infrastructure.

Judging from the current economic climate and the level of development of land relations, a broad understanding of the land market seems correct. Given the concept of marketing, it is the most relevant, in our opinion, to define the land market as a system of economic relations for the alienation of land plots and rights to them, which includes the following elements: goods, demand, offer, price, infrastructure, mechanisms of state regulation of land transactions.

Based on the above, one can generally conclude that the legislation of Ukraine needs to be reformed in terms of the systematization of mandatory payments for land owners and users through enshrining a single mandatory payment - land fees, at the Tax Code of Ukraine. In the case of statutory implementation of this proposal, epy land fee can be understood as a mandatory payment made by landowners and users to local budgets, payers of which are both physical and legal entities, for efficient and rational use of land as the basic national wealth of Ukraine.

3. Topical issues of the mechanism of collecting land fees in the context of the agricultural land market: the identification of fundamental problems and solutions

The analysis of the current mechanism of land use taxation grounded on regulatory and monetary value shows an equalizing system that does not take into account the rental income of land fees. As a result, the amount of tax does not depend on the intended purpose, usage pattern, and, most importantly, the outcome of the economic activity of a taxpayer. In the long run, it leads to violations of the principle of fair taxation of land use.

It should also be noted that the current mechanism of collecting land tax does not ensure the completeness, fairness, and generality of land taxation since it is related to the problem of registration and cadastral registration of land. In addition, according to the tax authorities, the information array they received often does not contain land title deeds (tax identification number (TIN), land address, cadastral number, etc.) and has many errors and inaccuracies: the same plots are duplicated under different cadastral numbers, the area of land plots is incorrect, most of them do not contain data on location and their owners; thus, it is impossible to identify landholders and guarantee appropriate tax administration. Consequently, the number of taxpayers registered with the tax authority at the location of the land does not match the number of taxpayers (Borzenkova, 2015, p. 42).

There remains a set of serious challenges that do not secure the complete formation of the tax base for land tax in the state. In particular, a serious challenge is the taxation of land use without title documents and proper registration of changes in the type of permitted land use. Ukrainian tax legis- 
lation does not allow the taxation of areas, which causes the loss of local budget revenues due to the non-calculation of the tax and its understatement (Dema, Sus, Trokoz, 2011 , p. 370). Agricultural lands are sometimes used as land taxed at the maximum rate, and tax authorities have no reason to collect maximum tax as land tax calculation is based exclusively on title documents and the type of permitted land use. Moreover, tax authorities do not have information on tax benefits that leads to incorrect determination of the tax base and the amount of accrued tax. Due to the above challenges upon identifying the substantial base for land tax, there appear to be differences in tax potential and the formation of budget revenues.

According to the authors, the current mechanism for collecting land fees contains shortcomings that do not ensure fair taxation. It is poorly differentiated in terms of property status, profits of economic activity of agricultural production. Differentiation rooted in the regulatory-monetary value rather characterizes the purpose of land plots than their intended use that does not stimulate the efficiency of land use and does not consider the socio-economic situation of an individual landowner - it is of critical importance amidst the high social inequality of the population of our state - especially of one who lives in rural areas and has small land plots as subsistence. Some researchers contend that the current mechanism of land taxation in general and in the context of the land market is not an effective tool for collecting and redistributing land rent (Yatsukh, 2018, p. 130). Thus, the analysis of the current system of land use taxation allows stressing that the improvement of the effectiveness of land tax is associated with the implementation of the rental concept of taxation aimed at deducting land rent conditioned by advantages of location, fertility, and quality of the land.

It should be stated that for the moment, Ukraine has developed a regulatory framework focused on advancing the efficiency of the agricultural land market and the use of land resources following their intended purpose and taxation principles. Pursuant to Arts. 271 and 286 of the Tax Code of Ukraine, a tax base comprises the statutory monetary valuation of land, taking into account the indexation coefficient, the area of land, the statutory monetary valuation of which is not carried out, and the data of the state land cadaster. The Order of the State Committee of Ukraine on Land Resources "On approval of Guidelines for expert monetary valuation of land plots" No. 118 as of 12.11.1998 approved Guidelines for expert monetary val- uation of land plots which contains the fundamental methodological principles, as follows: - the use of indicators of standard crop capacity(based on soil properties) and standard costs calculated on the ground of planning sheet; - the determination of the best and most efficient use of a land plot under the current type of land use; - the calculation of profit indicators of an entrepreneur and capitalization ratio for land plots.

At the same time, in the development of Guidelines, an array of key aspects which directly set the amount of the regulatory-monetary value of the land has not been addressed: 1. the procedure for performing calculations for plots the information on borders of which the state real estate cadaster lacks; 2 . it is not possible to compile explications of land areas by soil varieties without vectorization (digitization of soil maps); this type of work causes an increase in the cost of state cadastral valuation of agricultural land, but it is required because the obtained materials will have a various functional application; 3 . the guidelines do not contain unambiguous requirements for the procedure for fixing market (forecast) prices of marketing crops, the calculation of profit of a businessman and capitalization ratio. Such requirements must be clearly and unambiguously defined.

Nowadays, most authors propose to improve tax benefits and increase land tax rates for some categories of land as an alternative for the improvement of the mechanism of calculation and payment of land tax in Ukraine in the context of the agricultural land market (Sydorovych, Rudnytska, 2011, p. 115). According to the contributors, the advancement of the system of establishing and collecting land fees in the context of the land market is possible in two realms: a more detailed differentiation of the tax rate; the clarification of indicators of a regulatory-monetary value of land plots.

In the former case, it is essential to maintain at the state level for a reduction in the tax rate for agricultural land, from $0.3 \%$ to zero - if agricultural producers, who manufacture the most important products and food, are free of land fees in full. The advancement of the relevant system in the latter case should include timely updating of land valuation data and differentiation of cadastral and regulatory value of land plots depending on the purpose and permitted use. The cadastral value should be minimal for agricultural land; maximum for industrial lands. The introduction of differentiated indicators of the regulatory-monetary value of lands should also be carried out at the level of specific public authority. More- 
over, in the authors' opinion, when setting payments for agricultural land, it is crucial to consider their quality, location, and economic significance.

In general, several areas prevent the use of land tax in the context of the land market as a regulator of efficient land use:

1. Low investment activity. The investment attractiveness of land resources largely depends on the stability, certainty, and predictability of territory development, which can take place only if available approved documents of territorial planning of state entities. In addition, the slow involvement in the economic turnover of land plots of state or communal ownership also has a negative impact on the investment attractiveness of lands.

2. A lack of control over land use. According to the authors, the solution to this problem requires the following: - the analysis of principles and patterns of determining the market and cadastral value of land plots, comparability of results; - study of the legal regime of a land plot, i.e., permitted use of the land plot, prospects of urban development of the territory it is located on; - the study of characteristics of the land plot to find possible options for its use; - assessment and analysis of current land use.

3. A lack of coordinated activities of state authorities and local self-government to control the collection of land tax. The solution to this problem embraces: - active involvement of specialists who deal with professional evaluation and have expertise in establishing the regulatory-monetary value, commissioning of economic expert analysis; - the enhancement of interaction between public authorities and local government bodies which take part in land management and disposal; - additional administration and transfer of services related to accounting, monitoring, and analysis of land plots to specialized organizations in terms of the development of the public-private partnership.

One of the activity areas of local governments should be the involvement of unclaimed agricultural land plots in circulation; - the conversion of unclaimed land plots and agricultural land plots into state and local ownership; - the creation of conditions for legal registration of rights to land plots from agricultural lands, which are used by agricultural organizations and farm (agricultural) enterprises; - setting increased land tax rates in case of their nonuse for the intended purpose; - the registration of ownership of land plots that were legally allotted from the lands of former collective farms (kolkoz) based on shared ownership; identification of unaccounted land plots occupied by country houses, homestead buildings.
Thus, the implementation of a unified policy in the field of land relations, arrangement of the boundaries of land users, identification of irrational land use, involvement of unaccounted lands in taxation and civil turnover will contribute to land tax revenues, create a favorable investment climate that promotes the flow of additional financial resources to state and local budgets.

In general, the realization of the above proposals requires the development of legal rules regulating the serviceability of land tenure, land use; resumption of the practice of conducting special surveys and studies (including soil surveys); improvement of the theory and practice of land valuation; creation of an appropriate mechanism of the agricultural land market. These measures are aimed at improving economic instruments for regulating land use, organizing the rational use, and protecting land resources of the country and its regions.

\section{Conclusions}

When considering the land tax in the context of the land market as one of the main ways to advance the economic efficiency of agricultural producers, the authors hold it necessary to emphasize that it should be introduced: first, in proportion to income, economically and environmentally sound; secondly, it should not burden a payer with a high rate, or a complicated payment procedure or its inconvenient terms; third, tax rates should be in regression dependence on the dynamics of the quality of agricultural land; fourth, it is necessary to include it in a single system of financial circulation that its deduction and further use result in, at least, an indirect return to taxpayers through its targeted focus on environmental needs. Foreign experience confirms that tax regulation becomes effective when the land tax in the land market acquires an objective environmental focus, i.e., it returns to the level of rent-forming factors through the mechanism of the financial cycle, ensuring their sustainable reproduction.

Moreover, the land tax system must primarily encourage the owner and user to use, care for and maintain land efficiently. Secondly, the taxation system of agricultural producers must consider the peculiarities of this economic sector, the level of production potential, the outcomes of financial and economic activities of enterprises and their efficiency. Hence, the implementation of the principle of fair taxation of land use tax is achieved. Third, land taxation should overcome the landowners' visions of the system of free land and promote their careful treatment of it. 


\section{References:}

Borzenkova, O.D. (2015). Zemelne opodatkuvannia v Ukraini: analiz suchasnoho stanu ta perspektyvy [Land taxation in Ukraine: analysis of the current situation and prospects]. Hlobalni ta natsionalni problemy ekonomiky, vol. 8. (in Ukrainian).

Dema, D.I., Sus, Y.Y., Trokoz, V.M. (2011). Podatkovi naslidky reformuvannia zemelnykh vidnosyn [Tax consequences of land reform]. Visnyk Zhytomyrskoho natsionalnoho ahroekolohichnoho universytetu, vol. 2. (in Ukrainian).

Hetmanets, O.P., Shumila, O.M., Pokotaieva, O.V. ta in. (2013). Podatkove pravo Ukrainy : navch. Posib [Tax law of Ukraine: textbook. way]. Kyiv: Khai-Tek Pres. (in Ukrainian).

Ikonitskaya, H.A. (2005). Zemel'noe pravo RF [Land law of the Russian Federation]. Moskva: Yurist. (in Russian).

Krylatykh, E.N. (1997). Stanovlenie i razvitie sistemy regulirovaniya zemel'nykh otnosheniy [Formation and development of the system of regulation of land relations]. Problemy prognozirovaniya, no. 1 (in Russian).

Nazarenko, V.I., Shmelev, G.I. (2005). Zemel'nye otnosheniya i rynok zemli [Land relations and the land market]. Moskva: Pamyatniki istoricheskoy mysli. (in Russian).

Plotnikova, Y.I. (2015). Problemy vyznachennia poniattia «plata za zemliu» yak riznovydu podatku u zakonodavstvi Ukrainy [Problems of defining the concept of "land fee" as a type of tax in the legislation of Ukraine]. Prykarpatskyi yurydychnyi visnyk, vol. 3 (9), no. 2 (in Ukrainian).

Shulha, M.V. ta in. (2019). Velyka ukrainska yurydychna entsyklopediia: u 20 t. Zemelne ta ahrarne pravo [Great Ukrainian legal encyclopedia: in 20 volumes. Land and agricultural law]. Nats. akad. prav. nauk Ukrainy, In-t derzhavy i prava im. V. M. Koretskoho NAN Ukrainy, Nats. yuryd. un-t im. Yaroslava Mudroho, 2019. pp. 696 (in Ukrainian).

Sydorovych, O.Y., Rudnytska, Y.V. (2011). Suchasni tendentsii ta problemni aspekty zemelnoho opodatkuvannia $\mathrm{v}$ Ukraini [Current trends and problematic aspects of land taxation in Ukraine]. Naukovi zapysky Natsionalnoho universytetu "Ostrozka akademiia", vol. 17. (in Ukrainian).

Yatsukh, O.O. (2018). Osoblyvosti normatyvno-pravovoho zabezpechennia administruvannia platy za zemliu dlia tovarovyrobnykiv silskohospodarskoi produktsii [Features of regulatory and legal support for the administration of land fees for agricultural producers]. Prychornomorski ekonomichni studii, vol. 35. (in Ukrainian).

\section{Наталія Бондарчук,}

кандидат юридичних наук, доцент, Поліський національний університет, Старий бульвар, 7 , Житомир, Україна, індекс 10002, bondarchnat@ukr.net

ORCID: orcid.org/0000-0001-8432-6275

\section{Наталія Ліхтансъка,}

здобувач магістратури за спеціальністю «Право», Поліський начіональний університет, Старий бульвар, 7, Житомир, Україна, індекс 10002, lihtanskaа@gmail.com

ORCID: orcid.org/0000-0002-8963-9403

\section{Олена Тишкевич,}

здобувач магістратури за спеціальністю «Право», Поліський національний університет, Старий бульвар, 7, Житомир, Україна, індекс 10002, olenatiskevic@gmail.com

ORCID: orcid.org/0000-0003-4589-2914

\section{АКТУАЛЬНІ ПИТАННЯ МЕХАНІЗМУ ЗЕМЕЛЬНОГО ОПОДАТКУВАННЯ В УКРАЇНІ В КОНТЕКСТІ РИНКУ ЗЕМЕЛЬ СІЛЬСЬКОГОСПОДАРСЬКОГО ПРИЗНАЧЕННЯ}

Анотація. Метою статmi є аналіз чинного земельного, цивільного й податкового законодавства та доктринальних джерел для з'ясування сутності і правової природи плати за землю в контексті ринку земель сільськогосподарського призначення, ідентифікація та аналіз основних проблем і недоліків визначення ціни та справляння плати за землю, а також визначення місця й ролі цього податку у структурі доходів місцевих бюджетів України. Для визначення понять «плата за землю» та «ринок землі» в системі оподаткування України проаналізовано компоненти понятійно-категоріального апарату дослідження, встановлено зміст плати за землю в контексті ринку землі, виокремлено основні недоліки визначення ціни й механізму справлян- 
ня плати за землю, сформовано загальнотеоретичні пропозиції щодо оптимізації функціонування цього інституту.

Методи дослідження. Роботу виконано на підставі загальнонаукових і спеціальних методів наукового пізнання.

Результати. Звернено увагу на те, що законодавство України потребує реформування в напрямі систематизації обов'язкових платежів для власників і користувачів землі шляхом закріплення на рівні Податкового кодексу України єдиного обов'язкового платежу для зазначених платників податків - плати за землю. У разі реалізації цієї пропозиції на рівні законодавства під платою за землю можна буде розуміти обов'язковий платіж, який справляється з власників і користувачів землі до місцевих бюджетів із метою ефективного й раціонального використання земель як основного національного багатства України, а його платниками є як фізичні, так і юридичні особи. У статті виокремлено основні недоліки чинного механізму визначення ціни та справляння земельного податку. Зазначено, що підвищення ефективності земельного податку пов'язане з реалізацією рентної концепції оподаткування, спрямованого на вилучення земельної ренти, зумовленої перевагами розташування, родючості та якості земельних угідь. Запропоновано основні напрями вдосконалення системи встановлення та справляння плати за землю.

Висновки. Визначено, що земельний податок є одним із найголовніших способів підвищення економічної ефективності сільськогосподарських товаровиробників. Зроблено висновок про те, що встановлення земельного податку має відбуватися з огляду на такі умови: по-перше, він має бути пропорційним доходу, економічно й екологічно обгрунтованим; по-друге, він не повинен обтяжувати свого платника ні високою ставкою, ні складною процедурою сплати або незручними її термінами; по-третє, ставки податку мають перебувати в регресійній залежності від динаміки якості сільськогосподарських угідь; по-четверте, необхідно включити цей податок у єдину систему фінансового кругообігу, щоб від його вилучення та подальшого використання була хоча б непряма віддача платникам податків через його цільове спрямування на екологічні потреби.

Ключові слова: плата за землю, земельний податок, механізм оподаткування, державна політика, інвестиційна політика.

The article was submitted 14.10.2021

The article was revised 04.11.2021

The article was accepted 25.11.2021 